\title{
LARVAL MORPHOLOGY OF THE SESARMID CRAB ARMASES ANGUSTIPES DANA, 1852 (DECAPODA, BRACHYURA, GRAPSOIDEA)
}

\author{
José A. Cuesta and Klaus Anger
}

(JAC, correspondence) Departamento de Ecología, Facultad de Biología, Apdo. 1095, 41080 Sevilla, Spain (mariscal@cica.es), present address: Department of Biology, Laboratory for Crustacean Research,

University of Louisiana at Lafayette, P.O. Box 42451, Lafayette, Louisiana 70504-2451, U.S.A.; (KA) Biologische Anstalt Helgoland, Stiftung Alfred-Wegener-Institut für Polar- und Meeresforschung, 27498 Helgoland, Germany (kanger@awi-bremerhaven.de)

\section{A B S T R A C T}

\begin{abstract}
Larvae of the sesarmid crab Armases angustipes Dana, 1852, captured from the coast of the state of São Paulo, Brazil, were reared in the laboratory from hatching to the megalopa stage. In this paper, the morphology of the four zoeal stages and the megalopa is described and illustrated. Morphological comparisons are made with all known descriptions for the larvae of Armases including an unpublished description of A. angustipes and of some closely related genera (Aratus and Sesarma). Several differences to the previous description of A. angustipes are shown, and additional characters such as the previously undescribed cephalothoracic setation of the larval stages are described and illustrated. Diagnostic characters are provided to differentiate the American genera Sesarma and Armases.
\end{abstract}

The Sesarmidae Say, 1817, are represented in the Americas by four genera (Aratus $\mathrm{H}$. Milne Edwards, 1837; Armases Abele, 1992; Metopaulias Rathbun, 1896; Sesarma Say, 1817) with 29 species (for recent discussion of grapsoid taxonomy see Schubart et al., 2000). The genus Armases was erected by Abele (1992) with 11 species formerly assigned to the genus Sesarma. Later, Metasesarma rubripes Rathbun, 1897, was transferred to Armases by Niem, 1996. Within this genus, larval morphology has been described for the following species: A. cinereum (Bosc, 1802) by Costlow and Bookhout (1960) and Schubart and Cuesta (1998); A. ricordi (H. Milne Edwards, 1853) and A. rubripes (Rathbun, 1897) by Díaz and Ewald (1968) and Schubart and Cuesta (1998); A. angustipes Dana, 1852, by Kowalczuk (1994); and A. miersii (Rathbun, 1897) by Cuesta et al. (1999). According to Niem (1996) and Schubart et al. (2000), the monotypic Aratus pisonii (H. Milne Edwards, 1837) is also closely related to Armases and therefore is included in our morphological comparison (see Warner, 1968; Fransozo et al., 1998).

In adult morphology, Armases angustipes is very similar to $A$. miersii; the exact distribution and possible sympatry of these two species, e.g., in the Bahamas, remains unre- solved (Abele, 1992; Cuesta et al., 1999). However, clear differences are found when their larval morphology is compared. The main difference is the number of zoeal stages, with three in A. miersii (abbreviated development) and four in A. angustipes; further interspecific differences are found in their chaetotaxy. The larval development of A. angustipes was described from material originating from Farol Island, Brazil, in an unpublished Master of Science thesis by Kowalczuk (1994), but this did not meet fully with modern-day standards. In the present study, larval development of $A$. angustipes from the coast of the state of São Paulo (Brazil) is described and illustrated, intraspecific differences to the previous description are shown and discussed, and additional morphological characters are provided.

\section{MATERIALS AND Methods}

An ovigerous crab Armases angustipes was collected in February, 1996, at the vicinity of São Sebastião Marine Biological Station of the University of São Paulo (USP, São Paulo, Brazil) and transferred live to the Helgoland Marine Biological Station (Germany). Larvae hatched on 12 March; they were mass-reared at constant $24^{\circ} \mathrm{C}$ and $25 \%$ o using gently aerated beakers ( 11 , about 100 larvae per beaker). Water and food (Artemia sp., about 10 freshly hatched nauplii/ $/ \mathrm{ml}$ ) were changed daily, and the larvae were checked for moulting and mortality. The rearing salinity was obtained by dilution of filtered natural sea water from the North Sea $(32 \%$ ) with deion- 
ized water; this condition was chosen because a previous experimental study had shown that a slightly reduced salinity was more favorable for the larval development of this species than full-strength sea water (Anger et al., 1990). Samples of larvae and exuviae were fixed in $4 \%$ Formalin in sea water.

Drawings and measurements were made using a Wild MZ6 and an Olympus BH compound microscope, both equipped with a camera lucida. Semipermanent mounts were made of whole larvae; dissected appendages were stained using CMC 10 and lignin pink. All measurements were made with an ocular micrometer. Drawings were based on five larvae, size measurements on 10 larvae, per stage. In zoea larvae, rostrodorsal length (rdl) was measured from the tip of the rostral spine to the tip of the dorsal spine; carapace length $(\mathrm{cl})$ from the base of the rostrum to the posterior margin; carapace width (cw) as the greatest distance across the carapace. In the megalopa stage, carapace length (cl) was measured from the base of the rostrum to the posterior margin, and carapace width (cw) as the maximum width. Long aesthetascs of the antennules in Fig. 3, and the long natatory setae on the distal exopod segments of the first and second maxillipeds in Figs. 7 and 8 are drawn truncated. In Fig. 7, the basis of the zoea II-IV is not shown, because no differences in relation to that of zoea I were found; in Fig. 8, the second maxilliped of the zoea II and III are not shown, because they differed only in size. The long terminal natatory setae of the exopod of the second pleopod and uropod are truncated in Fig. 12. Description and figures are arranged according to the standard proposed by Clark et al. (1998).

Samples of larvae (zoea I to megalopa) of Armases angustipes were deposited at the Smithsonian Natural History Museum of Washington, under the catalog number USNM 266398.

\section{RESULTS}

The first zoeal stage of Armases angustipes is described completely. For the subsequent stages only the main differences from the first zoea are described in detail. Evolution of setation formulae and appendages through zoeal development is shown in Table 1.

\section{Description}

Armases angustipes Dana, 1852

(Figs. 1A, B; 2A, B; 3A-D; 4A-D; 5A-D; 6A-D; 7A-E; 8A-C; 9A-C; 10A-D; 11A-G; 12A-D)

\section{Zoea I}

Dimensions. - Rdl: $0.78 \pm 0.04 \mathrm{~mm}$; cl: 0.41 $\pm 0.02 \mathrm{~mm}$; cw: $0.44 \pm 0.02 \mathrm{~mm}$.

Carapace (Fig. 1A).-Globose, smooth, without tubercles. Dorsal spine present, well developed, clearly recurved. Rostral spine present, straight, equal in length to antennary protopod. Lateral spines absent. Pair of setae on posterodorsal and anterodorsal regions. Posterior and ventral margin without setae. Eyes sessile.
Antennule (Fig. 3A).-Uniramous. Endopod absent. Exopod unsegmented, with 3 aesthetascs and 2 setae all terminal.

Antenna (Fig. 4A).-Well-developed protopod reaching tip of rostral spine and bearing 2 unequal rows of spines. Exopod elongated, with 4 terminal setae (1 long, 1 middle, and 2 minute).

Mandible.-Endopod palp absent.

Maxillule (Fig. 5A).-Coxal endite with 6 plumodenticulate setae. Basial endite with 5 setae (1 cuspidate, 4 plumodenticulate). Endopod 2-segmented, with 1 seta in proximal segment and 1 subterminal and 4 terminal plumodenticulate setae in distal segment. Exopod seta absent. Epipod seta absent.

Maxilla (Fig. 6A).-Coxal endite bilobed, with $5+3$ plumodenticulate setae. Basial endite bilobed, with $5+4$ plumodenticulate setae. Endopod unsegmented, bilobed, with 2 +3 long plumodenticulate setae on inner and outer lobe respectively. Scaphognathite (exopod) with 4 plumose marginal setae and long, setose posterior process.

First Maxilliped (Fig. 7A).-Basis with 10 medial setae arranged 2,2,3,3. Endopod 5-segmented, with 2,2,1,2,5 (1 subterminal +4 terminal) setae. Exopod 2-segmented, distal segment with 4 long, terminal, plumose natatory setae.

Second Maxilliped (Fig. 8A).-Coxa without setae. Basis with 4 medial setae arranged 1,1,1,1. Endopod 3-segmented, with 0,1,6 (3 subterminal +3 terminal) setae. Exopod 2-segmented, distal segment with 4 long, terminal, plumose natatory setae.

Third Maxilliped.-Present as undifferentiated buds.

Pereiopods._-Present as undifferentiated bud.

Abdomen (Fig. 11A).-Five abdominal somites. Somites 2 and 3 with pair of dorsolateral processes. Somites 2-5 with pair of posterodorsal setae. Pleopods absent.

Telson (Fig. 11A).-Telson bifurcated, with 3 pairs of serrulate setae on posterior margin. Two rows of teeth in inner distal part of each furcal branch. 
Table 1. Evolution of setation formulae and appendages through zoeal development of Armases angustipes. Abbreviations: s, setation; a, aesthetasc; seg., segment; en, endopod; ep, epipod; ex, exopod. In carapace setation numbers indicate pairs of setae.

\begin{tabular}{|c|c|c|c|c|}
\hline & Zoea I & Zoea II & Zoea III & Zoea IV \\
\hline \multicolumn{5}{|l|}{ Carapace } \\
\hline Anterodorsal s & 1 & 3 & 3 & 4 \\
\hline Posterodorsal s & 1 & 1 & 1 & 1 \\
\hline Posterior margin s & 0 & 0 & 0 & 0 \\
\hline Ventral margin $\mathrm{s}$ & 0 & 1 & 4 & 7 \\
\hline \multicolumn{5}{|l|}{ Antennule } \\
\hline$a+s$ & $3+2$ & $4+1$ & $3+2$ & $6+1$ \\
\hline \multicolumn{5}{|l|}{ Antenna } \\
\hline Endopod & absent & minute bud & elongated bud & 2-segmented bud \\
\hline \multicolumn{5}{|l|}{ Maxillule } \\
\hline Exopodal setae & absent & present & present & present \\
\hline Coxal endite s & 6 & 6 & 6 & 7 \\
\hline Basial endite s & 5 & 7 & 8 & 11 \\
\hline \multicolumn{5}{|l|}{ Maxilla } \\
\hline Coxal endite s & $3+5$ & $3+5$ & $3+5$ & $4+6$ \\
\hline Basial endite s & $5+4$ & $5+4$ & $5+5$ & $6+5$ \\
\hline Scaphognathite & 4 & 8 & 13 & 20 \\
\hline \multicolumn{5}{|l|}{ First maxilliped } \\
\hline \multicolumn{5}{|l|}{ Endopod } \\
\hline Proximal seg. s & 2 & 2 & 2 & 2 \\
\hline 2nd seg. s & 2 & 2 & 3 & 3 \\
\hline 3rd seg. s & 1 & 1 & 2 & 2 \\
\hline 4th seg. s & 2 & 2 & 2 & 2 \\
\hline Distal seg. s & 5 & 5 & 5 & 6 \\
\hline Exopod & 4 & 6 & 8 & 10 \\
\hline \multicolumn{5}{|l|}{ Second maxilliped } \\
\hline \multicolumn{5}{|l|}{ Endopod } \\
\hline Proximal seg. s & 0 & 0 & 0 & 0 \\
\hline 2nd seg. s & 1 & 1 & 1 & 1 \\
\hline Distal seg. s & 6 & 6 & 6 & 6 \\
\hline Exopod & 4 & 6 & 8 & 10 \\
\hline Third maxilliped & minute bud & small bud & $\begin{array}{l}\text { exopod and endopod } \\
\text { differentiated }\end{array}$ & $\begin{array}{c}\text { now epipod also } \\
\text { differentiated }\end{array}$ \\
\hline Pereiopods & minute buds & small buds & elongated buds & cheliped chelated \\
\hline \multicolumn{5}{|l|}{ Abdomen } \\
\hline Proximal somite s & 0 & 0 & 1 & 3 \\
\hline 2nd somite $\mathrm{s}$ & 2 & 2 & 2 & 2 \\
\hline 3rd somite $\mathrm{s}$ & 2 & 2 & 2 & 2 \\
\hline 4th somite $\mathrm{s}$ & 2 & 2 & 2 & 2 \\
\hline 5 th somite $\mathrm{s}$ & 2 & 2 & 2 & 2 \\
\hline 6th somite s & absent & absent & slightly developed & developed \\
\hline
\end{tabular}

\section{Zoea II}

Dimensions.—Rdl: $0.97 \pm 0.03 \mathrm{~mm}$; cl: 0.53 $\pm 0.02 \mathrm{~mm}$; cw: $0.68 \pm 0.01 \mathrm{~mm}$.

Carapace (Fig. 1B).-Three pairs of anterodorsal setae. Each ventral margin with 1 plumodenticulate seta. Eyes stalked. Otherwise unchanged.

Antennule (Fig. 3B).-Exopod with 1 additional shorter terminal aesthetasc and 1 seta. Otherwise unchanged.

Antenna (Fig. 4B).-Endopod bud present. Otherwise unchanged.
Mandible.-Unchanged.

Maxillule (Fig. 5B).-Basial endite with 7 setae. Exopod present as long, plumose marginal seta. Otherwise unchanged.

Maxilla (Fig. 6B).-Scaphognathite with 5 +3 plumose marginal setae, long posterior process now reduced in size. Otherwise unchanged.

First Maxilliped (Fig. 7B).-Exopod distal segment with 6 long, terminal, plumose natatory setae. Otherwise unchanged.

Second Maxilliped.-Exopod distal segment 


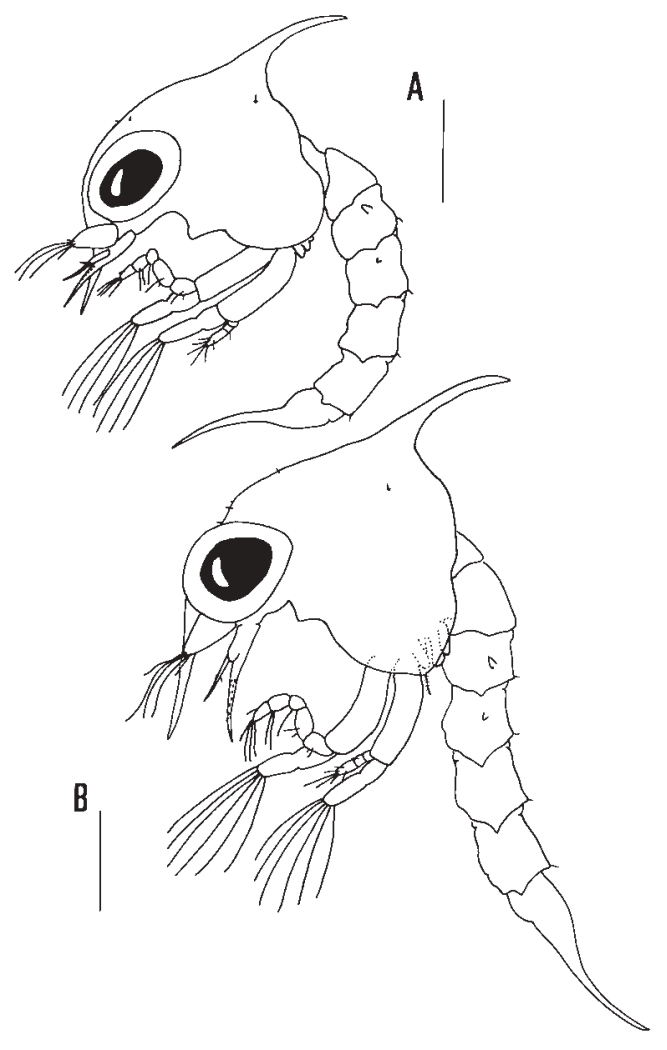

Fig. 1. Armases angustipes Dana, 1852. A, Zoea I; B, Zoea II. Scale bars $=0.2 \mathrm{~mm}$.

with 6 long, terminal, plumose natatory setae. Otherwise unchanged.

Third Maxilliped.-More elongated bud.

Pereiopods.-More elongated buds.

Abdomen (Fig. 11B).-Unchanged.

Telson (Fig. 11B).-Unchanged.

\section{Zoea III}

Dimensions.—Rdl: $1.21 \pm 0.03 \mathrm{~mm}$; cl: 0.66 $\pm 0.03 \mathrm{~mm}$; cw: $0.82 \pm 0.02 \mathrm{~mm}$.

Carapace (Fig. 2A).-Each ventral margin with 4 plumodenticulate setae. Otherwise unchanged.

Antennule (Fig. 3C).--Exopod unsegmented, with 3 aesthetascs and 2 setae. Otherwise unchanged.

Antenna (Fig. 4C).-Endopod bud elongated, as long as exopod. Otherwise unchanged.

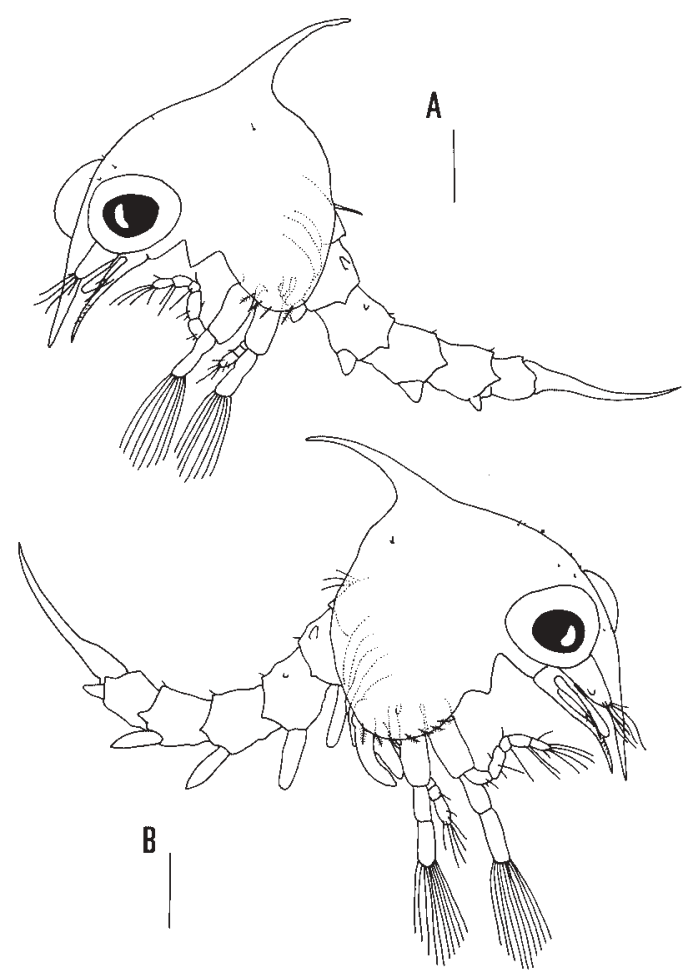

Fig. 2. Armases angustipes Dana, 1852. A, Zoea III; B, Zoea IV. Scale bars $=0.2 \mathrm{~mm}$.

Mandible.-Unchanged.

Maxillule (Fig. 5C).-Basial endite with 8 setae. Epipod seta present. Otherwise unchanged.

Maxilla (Fig. 6C).-Basial endite bilobed, with $5+5$ setae. Scaphognathite with 13 plumose marginal setae. Otherwise unchanged.

First Maxilliped (Fig. 7C).-Endopod segments 2 and 3 each with additional dorsal seta. Exopod distal segment with 8 long, terminal, plumose natatory setae. Otherwise unchanged.

Second Maxilliped.-Exopod distal segment with 8 long, terminal, plumose natatory setae. Otherwise unchanged.

Third Maxilliped (Fig. 9A).-Biramous, unsegmented.

Pereiopods (Fig. 10A).-Present, unsegmented. Chelipeds bilobed.

Abdomen (Fig. 11C)._-First somite with 1 long mid-dorsal seta. Somite six now present, 

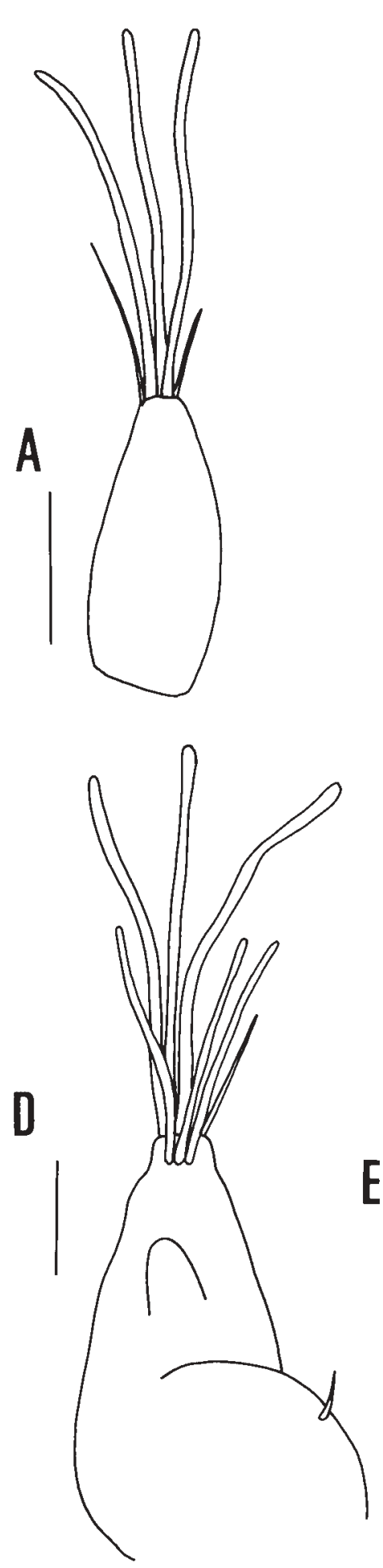

Fig. 3. Armases angustipes Dana, 1852, antennule. A, Zoea I; B, Zoea II; C, Zoea III; D, Zoea IV; E, Megalopa. Scale bars $=0.05 \mathrm{~mm}$.

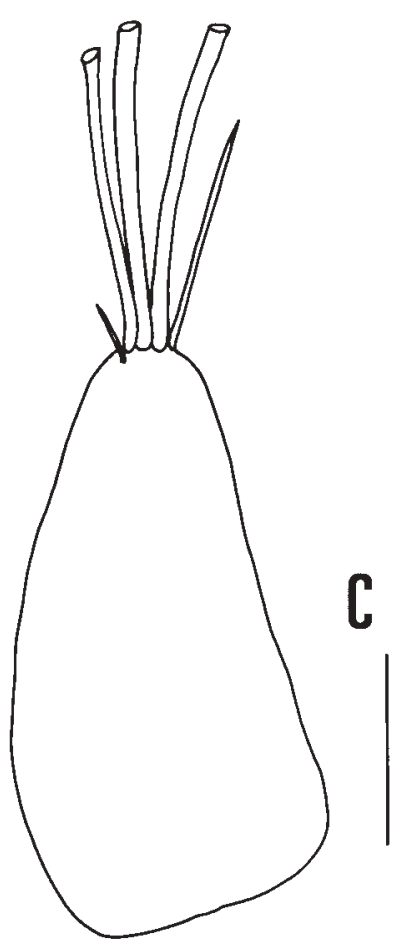



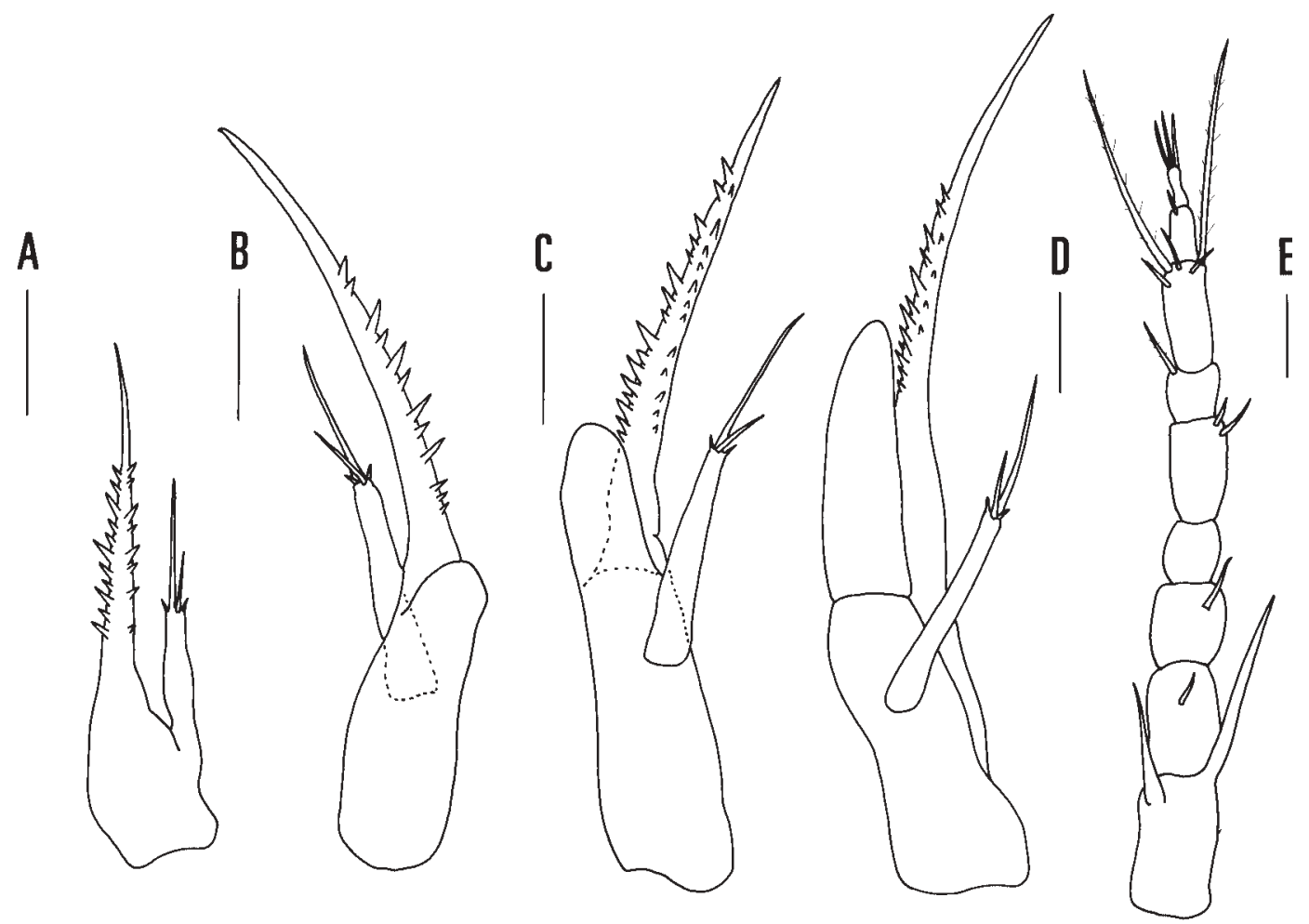

Fig. 4. Armases angustipes Dana, 1852, antenna. A, Zoea I; B, Zoea II; C, Zoea III; D, Zoea IV; E, Megalopa. Scale bars $=0.05 \mathrm{~mm}$.

without setae. Pleopod buds present on somites 2-5, endopods absent. Otherwise unchanged.

Telson (Fig. 11C).-Unchanged.

\section{Zoea IV}

Dimensions. - Rdl: $1.30 \pm 0.04 \mathrm{~mm}$; cl: 0.71 $\pm 0.02 \mathrm{~mm}$; cw: $0.89 \pm 0.03 \mathrm{~mm}$.

Carapace (Fig. 2B).-Four pairs of anterodorsal setae. Each ventral margin with 7 plumodenticulate setae. Otherwise unchanged.

Antennule (Fig. 3D).-Now biramous. Endopod bud present. Exopod unsegmented, with 1 basal seta, 6 aesthetascs ( 3 subterminal, 3 terminal), and 1 terminal seta.

Antenna (Fig. 4D).-Endopod 2-segmented, longer reaching middle of protopod length. Otherwise unchanged.

Mandible.-Palp bud present.

Maxillule (Fig. 5D).-Coxal endite with 7 plumodenticulate setae. Basial endite with 11 setae. Otherwise unchanged.

Maxilla (Fig. 6D).-Coxal endite bilobed, with $6+4$ setae. Basial endite bilobed with $6+5$ setae. Scaphognathite with 20 or 21 plumose marginal setae. Otherwise unchanged.

First Maxilliped (Fig. 7D).-_Fifth segment of endopod with additional subterminal seta. Exopod distal segment with 10 long, plumose, natatory setae on distal segment. Otherwise unchanged.

Second Maxilliped (Fig. 8B).--Exopod distal segment with 10 long, plumose, natatory setae on distal segment. Otherwise unchanged.

Third Maxilliped (Fig. 9B).-Epipod rudiment now present.

Pereiopods (Fig. 10B).-Cheliped and pereiopods 2-5 slightly segmented.

Abdomen (Fig. 11D).-First somite with 3 long mid-dorsal setae. Pleopod buds elon- 

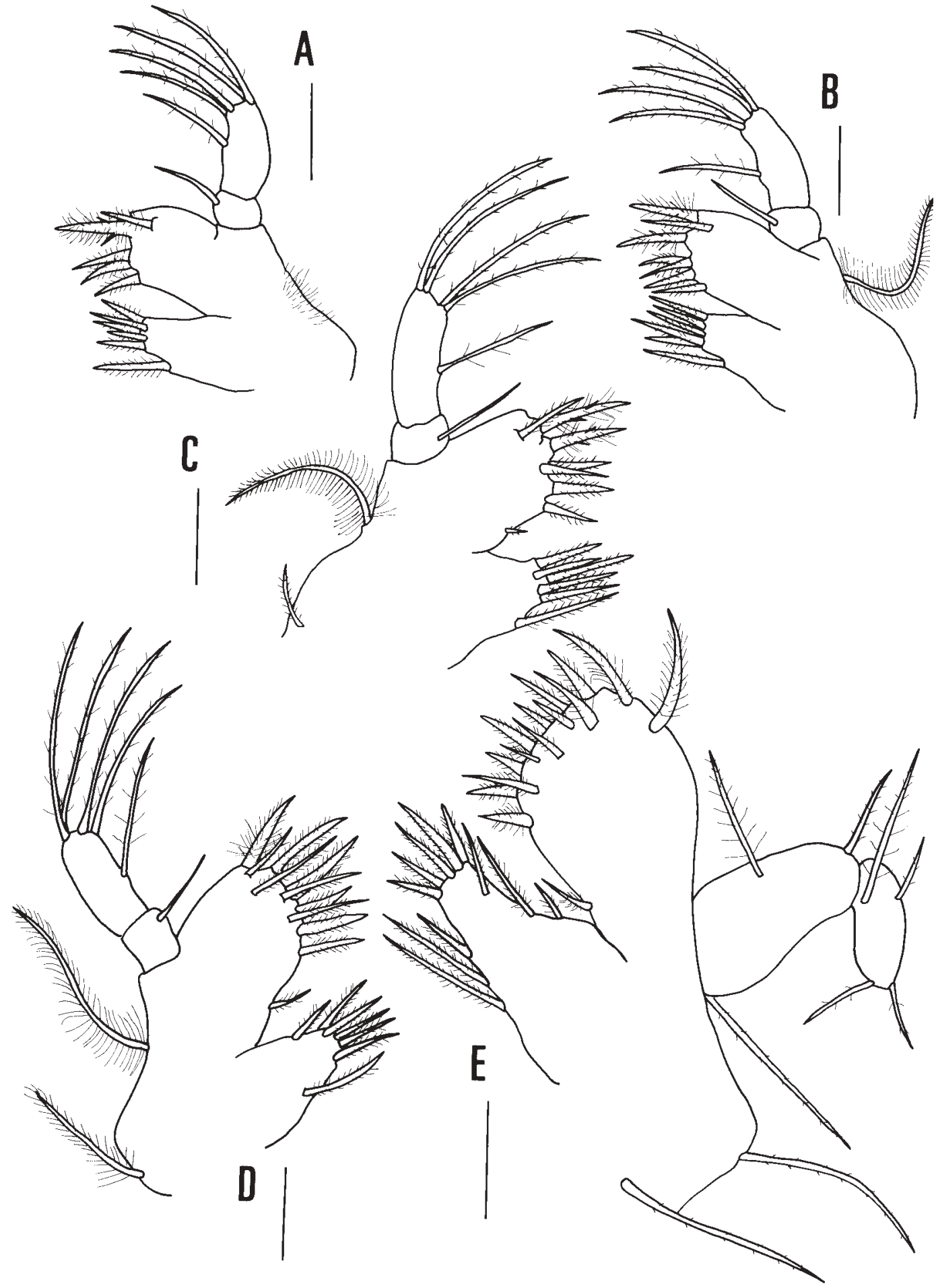

Fig. 5. Armases angustipes Dana, 1852, maxillule. A, Zoea I; B, Zoea II; C, Zoea III; D, Zoea IV; E, Megalopa. Scale bars $=0.05 \mathrm{~mm}$. 


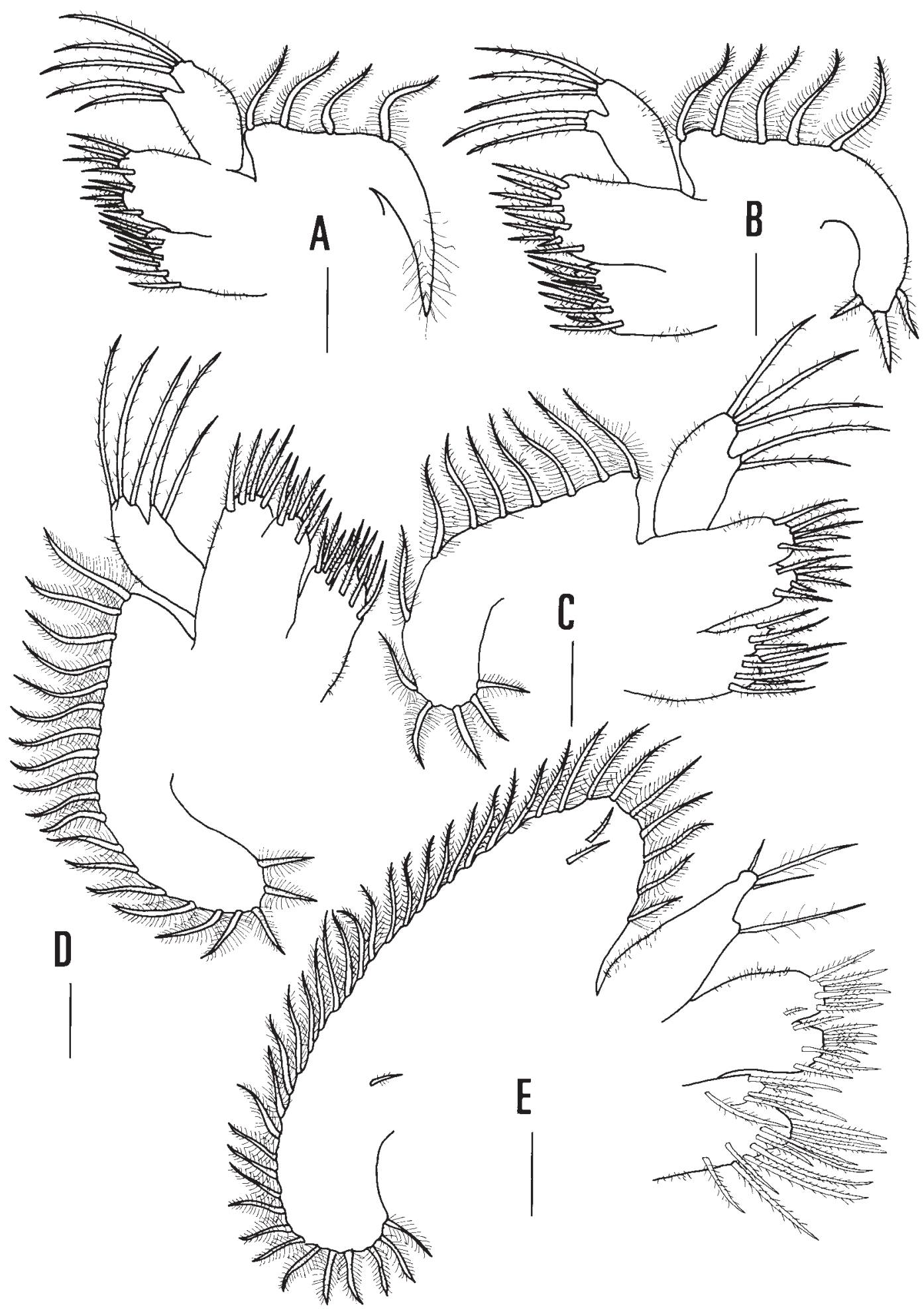

Fig. 6. Armases angustipes Dana, 1852, maxilla. A, Zoea I; B, Zoea II; C, Zoea III; D, Zoea IV; E, Megalopa. Scale bars $=0.05 \mathrm{~mm}$. 


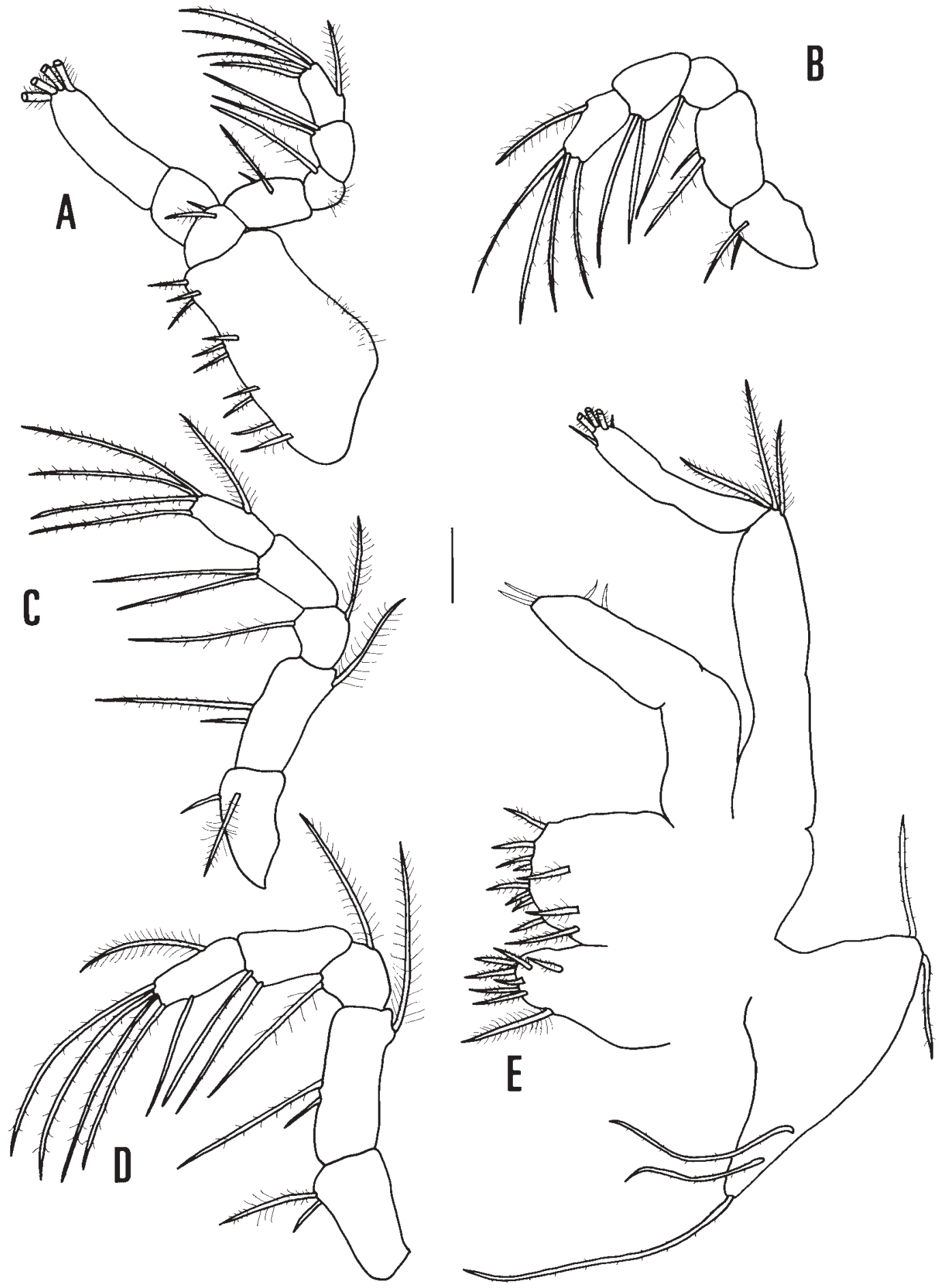

Fig. 7. Armases angustipes Dana, 1852, first maxilliped. A, Zoea I; B, Zoea II, endopod; C, Zoea III, endopod; D, Zoea IV, endopod; E, Megalopa. Scale bars $=0.05 \mathrm{~mm}$. 


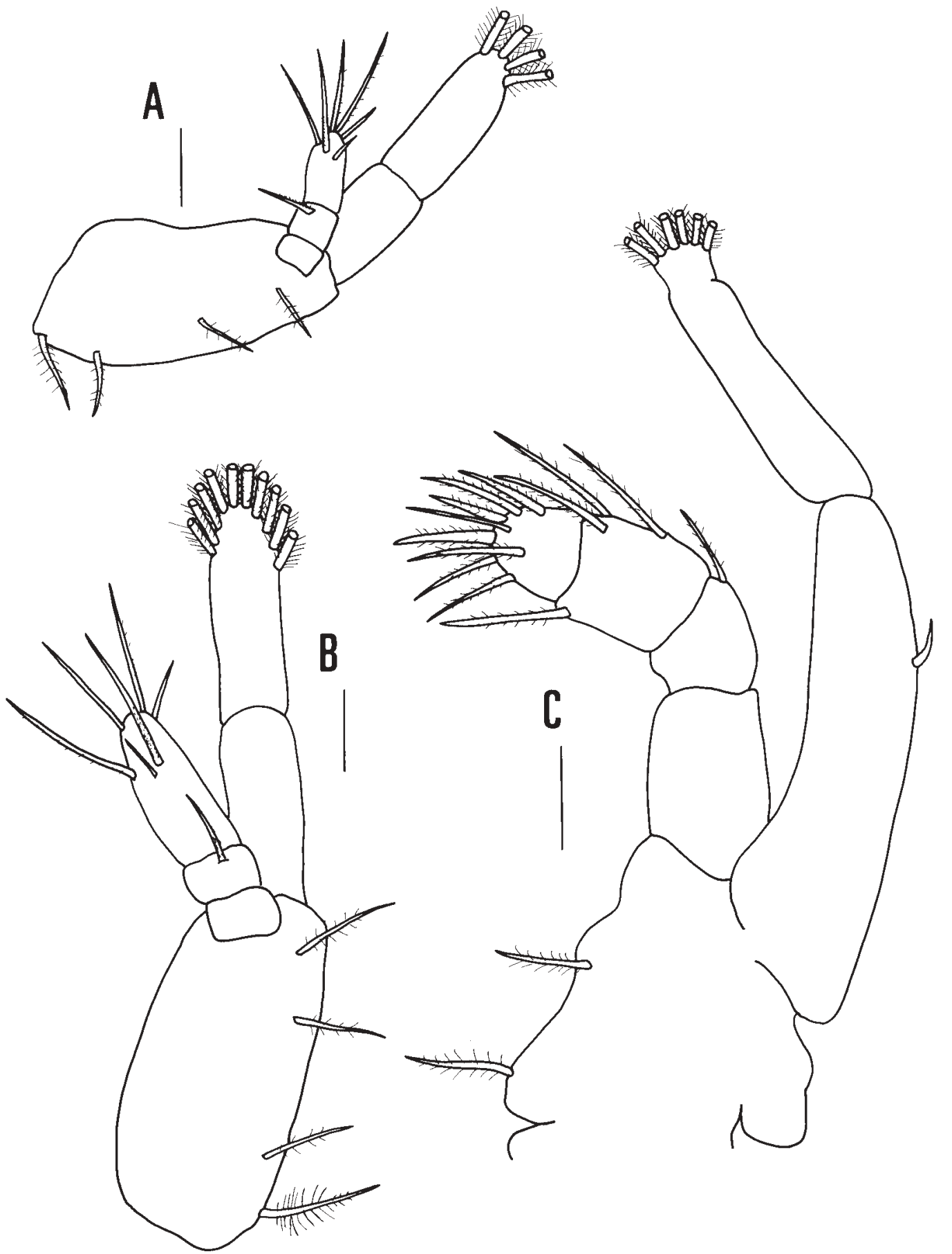

Fig. 8. Armases angustipes Dana, 1852, second maxilliped. A, Zoea I; B, Zoea IV; C, Megalopa. Scale bars $=0.05$ $\mathrm{mm}$. 


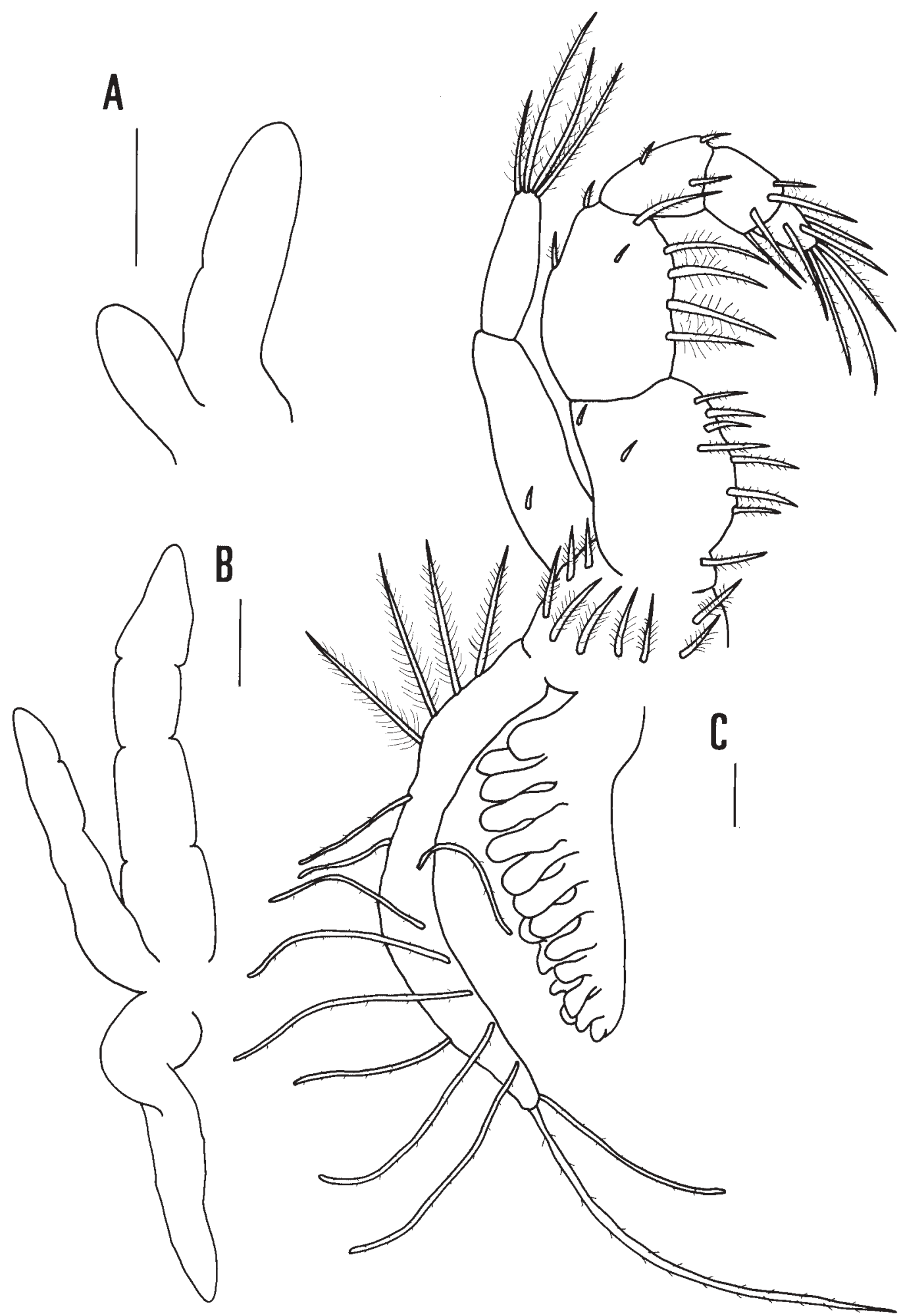

Fig. 9. Armases angustipes Dana, 1852, third maxilliped. A, Zoea III; B, Zoea IV; C, Megalopa. Scale bars $=0.05$ $\mathrm{mm}$. 


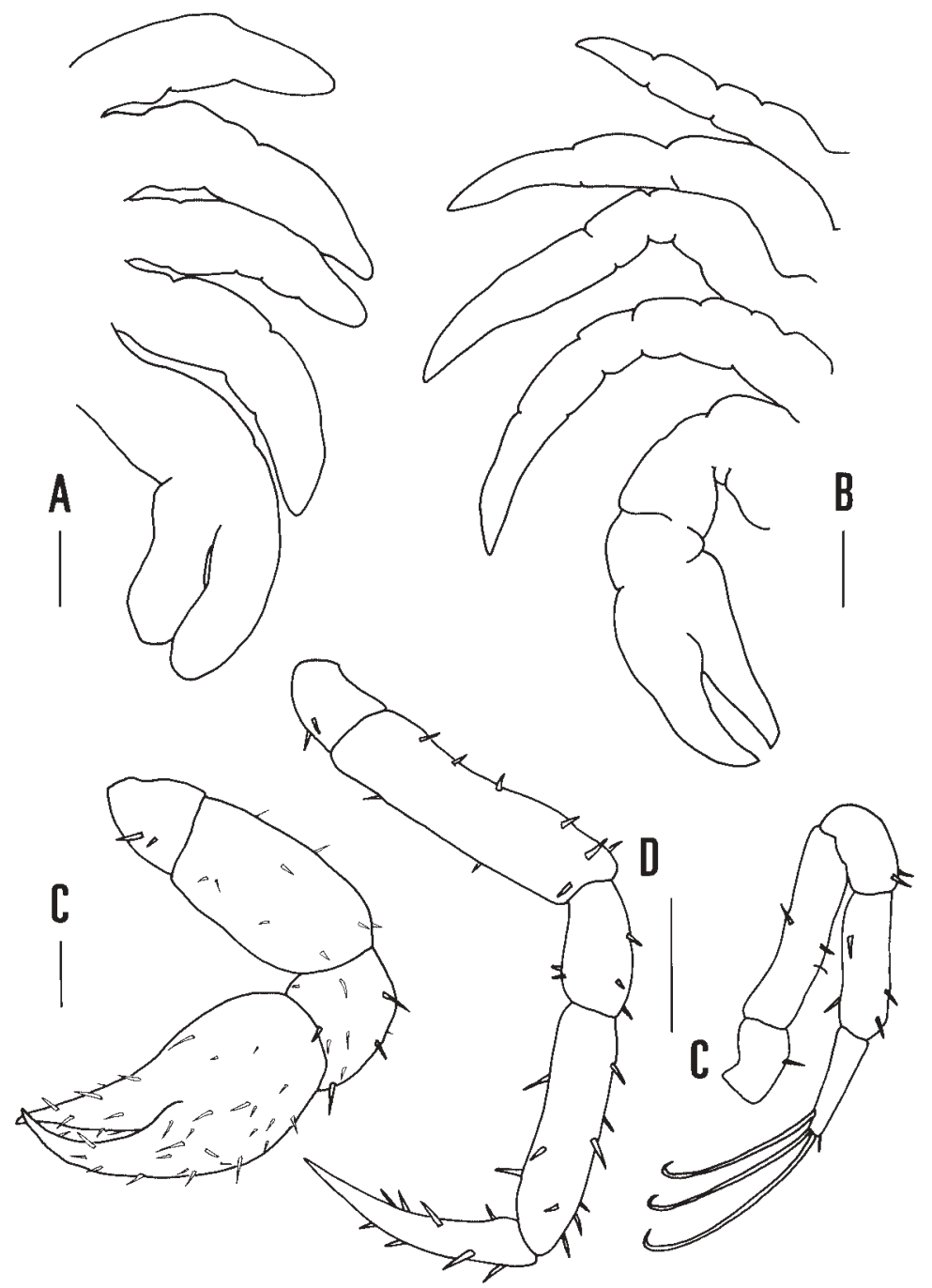

Fig. 10. Armases angustipes Dana, 1852, pereiopods. A, Zoea III; B, Zoea IV; C, Megalopa, cheliped; D, Megalopa, third pereiopod; E, Megalopa, fifth pereiopod. Scale bars $=0.05 \mathrm{~mm}$.

gated, endopod buds present. Otherwise unchanged.

Telson (Fig. 11D).-Unchanged.

\section{Megalopa}

Dimensions. $-\mathrm{Cl}: 0.66 \pm 0.05 \mathrm{~mm}$; cw: 0.48 $\pm 0.03 \mathrm{~mm}$.

Carapace (Fig. 12A).--Longer than broad. Rostrum ventrally deflected (approximately $90^{\circ}$ ), with median cleft. Setal arrangement as figured.

Antennule (Fig. 3E).-Peduncle 3-segmented, with 4,1,1 setae respectively. Endopod absent.
Exopod 3-segmented, with 0, 6, and 3 aesthetascs respectively and 0,2,2 (1 terminal long, plumose seta) setae.

Antenna (Fig. 5E).-Peduncle 3-segmented, with $0,1,1$ setae respectively. First segment retaining the exopod and modified protopod. Flagellum 6-segmented, with 0,2,1,5,1,3 setae respectively.

Mandible (Fig. 12B).-Palp 2-segmented, with 4 (1 subterminal, 3 terminal) setae on distal segment.

Maxillule (Fig. 5E).-Coxal endite with 11 setae. Basial endite with 15 setae. Endopod 

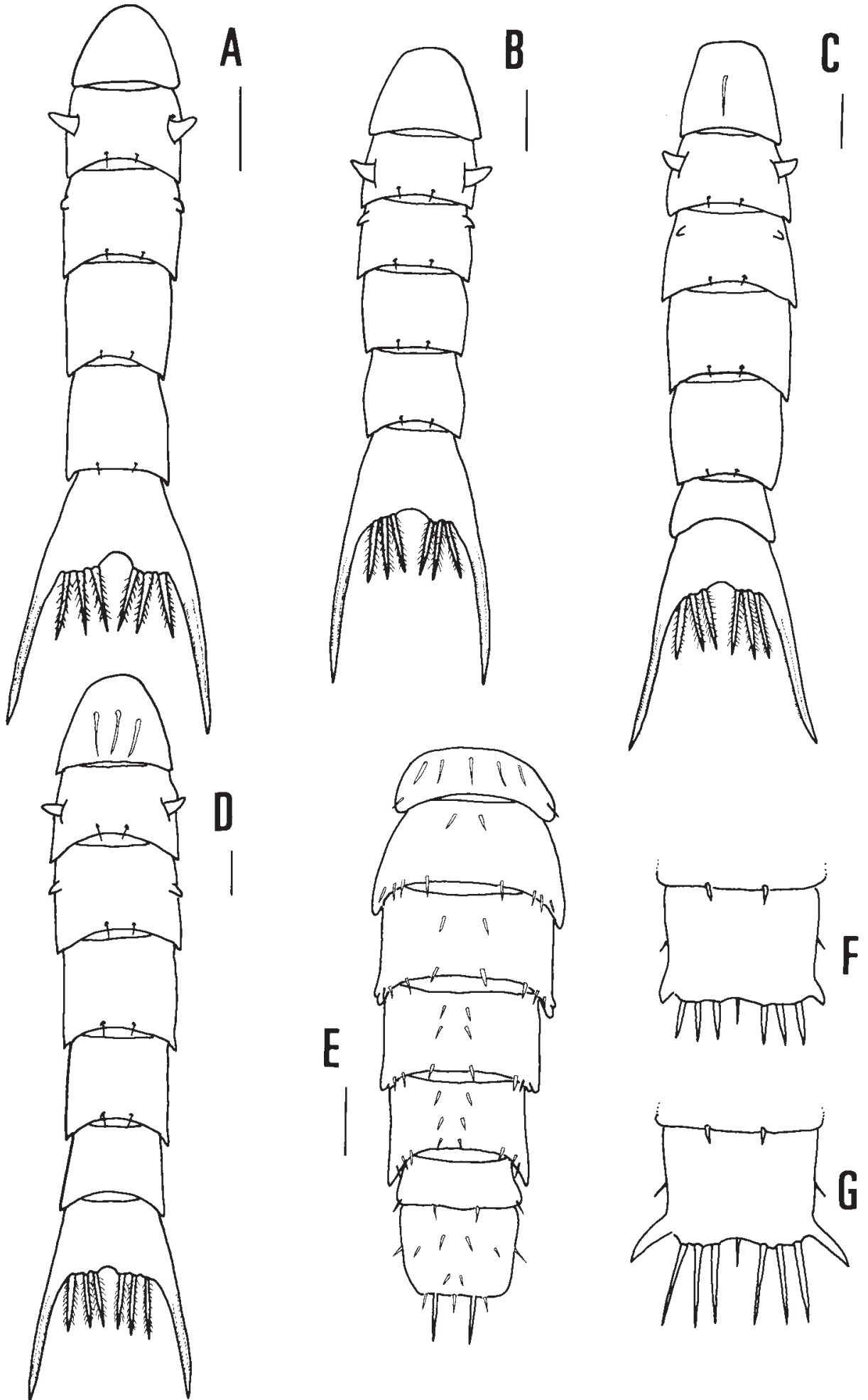

Fig. 11. Armases angustipes Dana, 1852, abdomen. A, Zoea I; B, Zoea II; C, Zoea III; D, Zoea IV; E, Megalopa; F, modified telson; G, modified telson. Scale bars $=0.1 \mathrm{~mm}$. 

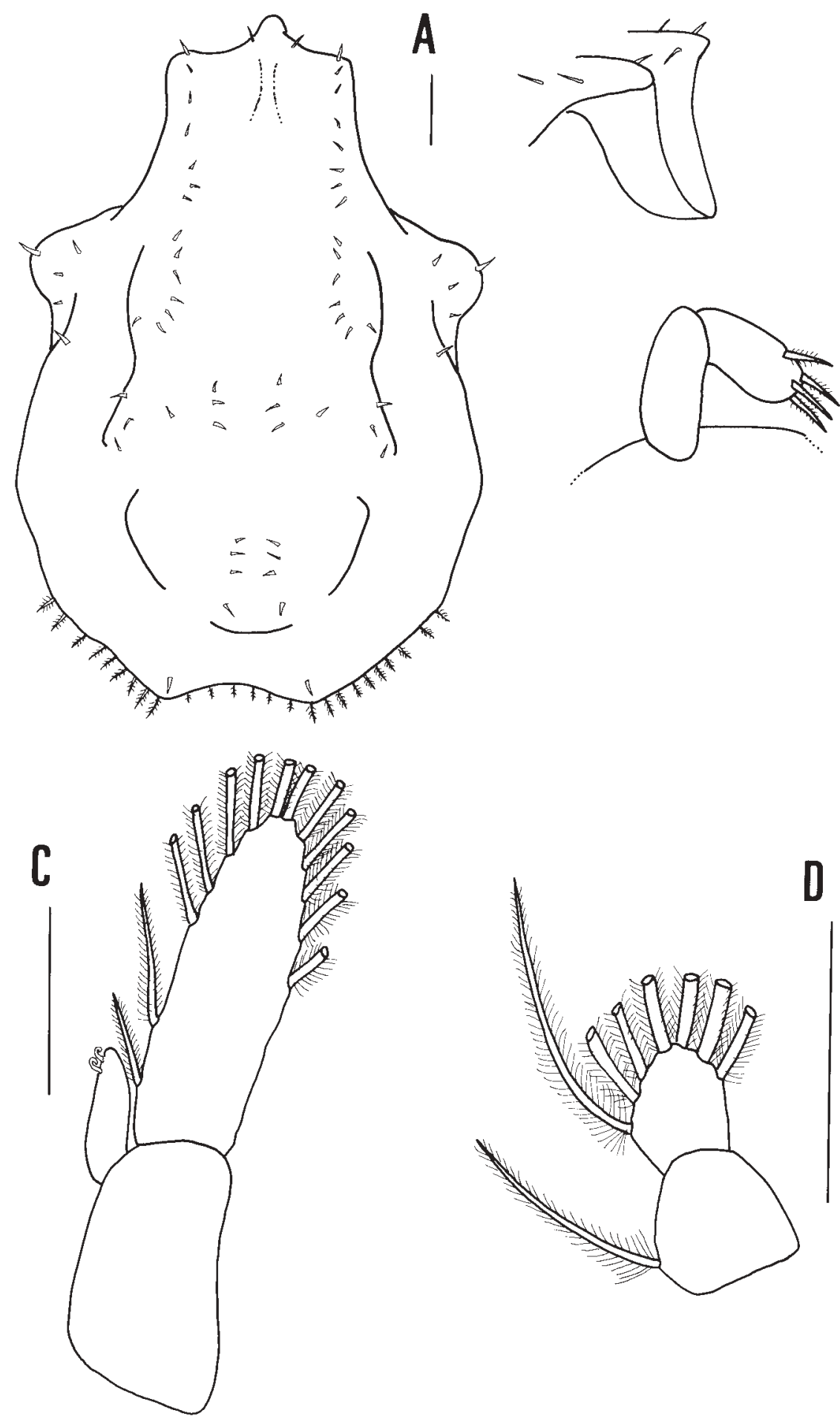

Fig. 12. Armases angustipes Dana, 1852, Megalopa. A, dorsal view of the cephalothorax and detail of lateral view of the rostrum; B, palp of the mandible; C, first pleopod; D, uropod. Scale bars $=0.1 \mathrm{~mm}$. 
2-segmented, proximal segment with 2 setae, distal segment with 4 setae ( 2 basal, 2 terminal).

Maxilla (Fig. 6E).-Coxal endite bilobed, with 11 (5 inner) + 5 (1 inner) plumodenticulate setae. Basial endite bilobed, with 8 (3 inner $)+7$ (1 inner) plumodenticulate setae. Endopod unsegmented, with 1 long subterminal seta and 3 terminal setae. Scaphognathite with 39 plumose marginal setae and 2 anterior and 1 posterior lateral setae.

First Maxilliped (Fig. 7E).-Epipod with 5 long setae. Coxal endite with 8 plumodenticulate setae ( 3 inner). Basial endite with 11 plumodenticulate setae ( 3 inner). Endopod slightly 2-segmented, with 4 simple terminal setae. Exopod 2-segmented, proximal segment with 3 distal, long plumodenticulate setae, distal segment with 4 long, terminal, plumose feeding setae.

Second Maxilliped (Fig. 8C).-Epipod rudimentary. Coxa and basis not differentiated, with 2 setae. Endopod 4-segmented with $0,1,4,8$ plumodenticulate setae respectively. Exopod 2-segmented, proximal segment with 1 medial seta, distal segment with 6 long, terminal, plumose feeding setae.

Third Maxilliped (Fig. 9C).-Epipod elongated with 15 long setae. Gill present. Coxa and basis not differentiated with 9 plumodenticulate setae. Endopod 5-segmented, ischium, merus, carpus, propodus and dactylus with $10,8,3,4$ and 6 (3 subterminal, 3 terminal) plumodenticulate setae respectively. Exopod 2-segmented, proximal segment with 1 simple basal seta and distal segment with 4 long terminal plumose raptatory setae.

Pereiopods (Fig. 10C-E).-All segments well differentiated and with setae as figured. Dactylus of fifth pereiopod with three long terminal setae and 1 short terminal spine (Fig. 10E).

Abdomen (Figs. 11E, 12C, D).--Six somites present. Somite 1 with 1 pair of lateral setae and 5 mid-dorsal simple setae. Setation on somites 2 to 6 as figured. Somites $2-5$ each with pair of biramous pleopods, endopod unsegmented, with 3 terminal hooks, exopod unsegmented; pleopods $1-4$ with $13,16,17,15$ long marginal plumose natatory setae respectively. Uropods 2-segmented on somite 6 , proximal segment with 1 and distal seg- ment with 7 long, marginal, plumose natatory setae respectively.

Telson (Fig. 11E-G).-Shape square, with pair of lateral setae, 3 pairs of middle setae, and 2 long and 3 short setae on posterior margin. In several cases, telson with 3 pairs of long setae and 1 middle seta on posterior margin; furcal branches present in 2 different degrees of development (Fig. 11F, G).

\section{DisCUSSION}

Cuesta et al. (1999) compared larval characters and setation patterns of Aratus with those of Armases and showed differences between $A$. angustipes and A. miersii. However, these species also share some characters that distinguish them from the rest of the Armases species for which larval descriptions have become available: (a) the setation pattern of the endopod of the first maxilliped; (b) both species have six setae on the coxal endite of the maxillule, whereas the others have only five; (c) the antennal exopod has in both species four terminal simple setae, but there are two or three in the other Armases species.

A comparison of the previous description of the larval development of A. angustipes (Kowalczuk, 1994) and the present results is given in Table 2. The setation of the carapace was not described by Kowalczuk (1994) and therefore this character cannot be compared here; a detailed description is given above (see text and figures). Hence, this character is not included in Table 2. An important difference was found in the setation of the antennal exopod, which has two or three terminal setae in Kowalczuk's material but four in the present material. Within the genus Armases, this character is shared only with $A$. miersii. Another important difference was observed on the inner surface of the scaphognathite of the megalopal maxilla. In the present study, two setae were observed on the anterior and one seta on the posterior area; the latter was not described by Kowalczuk (1994). This is significant insofar as the setation $(2+1)$ is a typical character which allows one to distinguish sesarmid megalopae from all other grapsoid megalopae (Cuesta, 1999). Further differences show intraspecific variation in the setation of various appendages.

Most of the megalopa characters described in the present study for A. angustipes showed 
Table 2. Morphological differences between larval-development descriptions of Armases angustipes given by Kowalczuk (1994) and in the present study. Abbreviations: s, setation; a, aesthetasc; seg., segment; dlp, dorsolateral processes; en, endopod; ep, epipod; ex, exopod.

\begin{tabular}{|c|c|c|}
\hline & $\begin{array}{l}\text { Armases angustipes } \\
\text { (Kowalczuk, 1994) }\end{array}$ & $\begin{array}{l}\text { Armases angustipes } \\
\text { (present study) }\end{array}$ \\
\hline \multicolumn{3}{|l|}{ ZOEA I } \\
\hline \multicolumn{3}{|l|}{ Antenna } \\
\hline Exopod s & $2-3$ & 4 \\
\hline Third maxilliped & No data & Small buds \\
\hline Pereiopods & No data & Small buds \\
\hline Abdomen dlp & Somite 2 & Somites 2 and 3 \\
\hline \multicolumn{3}{|l|}{ ZOEA II } \\
\hline Antennule $\mathrm{a}+\mathrm{s}$ & $3+2$ & $4+1$ \\
\hline \multicolumn{3}{|l|}{ Antenna } \\
\hline Exopod s & $2-3$ & 4 \\
\hline \multicolumn{3}{|l|}{ Maxilla } \\
\hline Scaphognathite s & $5+2$ & $5+3$ \\
\hline Third maxilliped & No data & Elongated buds \\
\hline Pereiopods & No data & Elongated buds \\
\hline \multicolumn{3}{|l|}{ Abdomen } \\
\hline Somite $1^{\circ}$ & 1 long mid-dorsal seta & mid-dorsal seta not present \\
\hline \multicolumn{3}{|l|}{ ZOEA III } \\
\hline Antennule $\mathrm{a}+\mathrm{s}$ & $3+1$ & $3+2$ \\
\hline \multicolumn{3}{|l|}{ Antenna } \\
\hline Exopod s & $2-3$ & 4 \\
\hline \multicolumn{3}{|l|}{ Maxilla } \\
\hline Basial endite s & $5+4$ & $5+5$ \\
\hline Scaphognathite s & $11-15$ & 13 \\
\hline Third maxilliped & No data & Elongated buds \\
\hline Pereiopods & No data & Elongated buds \\
\hline \multicolumn{3}{|l|}{ ZOEA IV } \\
\hline Antennule $\mathrm{a}+\mathrm{s}$ & $6+1$ & $6+2$ \\
\hline \multicolumn{3}{|l|}{ Antenna } \\
\hline Exopod s & $2-3$ & 4 \\
\hline \multicolumn{3}{|l|}{ Maxilla } \\
\hline Basial endite s & $5-6+4-6$ & $6+5$ \\
\hline Scaphognathite s & $19-23$ & $20-21$ \\
\hline \multicolumn{3}{|l|}{ First maxilliped } \\
\hline Exopod s & 9 & 10 \\
\hline \multicolumn{3}{|l|}{ MEGALOPA } \\
\hline \multicolumn{3}{|l|}{ Antennule } \\
\hline peduncle s & $5,1,1$ & $4,1,1$ \\
\hline \multicolumn{3}{|l|}{ Antenna } \\
\hline peduncle s & $0,1,1$ & 0 (exopod + protopod $), 1,1$ \\
\hline flagellum s & $0,3,1,5,1,2$ & $0,2,1,5,1,3$ \\
\hline \multicolumn{3}{|l|}{ Maxillule } \\
\hline Coxal endite s & 13 & 11 \\
\hline Basial endite s & 18 & 15 \\
\hline Maxilla & & \\
\hline Basial endite s & $8+6$ & $8+7$ \\
\hline Endopod s & unarmed & 1,3 \\
\hline Scaphognathite margin s & $34-37$ & 39 \\
\hline Scaphognathite inner s & 2 & $2+1$ \\
\hline First maxilliped & & \\
\hline Endopod s & unarmed & 2,2 \\
\hline Exopod s & 3,3 & 3,4 \\
\hline Epipod s & 7 & 5 \\
\hline Second maxilliped & & \\
\hline Endopod s & $0,1,3,6$ & $0,1,4,8$ \\
\hline Exopod s & 1,5 & 1,6 \\
\hline Third maxilliped & & \\
\hline Protopod s & 10 & 9 \\
\hline Endopod s & $9,8,4,4,5$ & $10,8,3,4,6$ \\
\hline Exopod s & 1,5 & 1,4 \\
\hline Epipod s & 16 & 15 \\
\hline
\end{tabular}


morphological peculiarities that differ clearly from those described by Kowalczuk (1994). The characters all represent remnants of zoeal morphology: (1) the first segment of the antennular peduncle has a rudimentary exopod and protopod; (2) the endopod of the maxilla is bilobed and with similar setation as in the zoeas (but with setation 1,3 instead of $2,3)$; (3) the telson shows a rudimentary furca and three pairs of serrulate setae on the posterior margin. The other morphological and meristic characters showed no important differences to Kowalczuk's description.

Similar traits were found also in the megalopae of two other American sesarmid species. The megalopae of Aratus pisonii (as described by Warner, 1968) and Sesarma reticulatum (see Costlow and Bookhout, 1962) showed the same remaining zoeal characters. In the case of Aratus pisonii the first segment of the antennular peduncle retained only the protopod, and the megalopa showed a small dorsal spine on the cephalothorax. The megalopa of $S$. reticulatum had an exopod on the first segment of the antennular peduncle, and it retained a long and straight rostral spine on the cephalothorax instead of the normally short and ventrally deflected rostrum. In both species, the megalopae have on the endopod of the maxillule the same morphology and setation as in the zoeal stages (2segmented, setation: $1,1+2+2$ ).

The retainment of zoeal characters in the megalopa is difficult to explain, if this is a species-specific trait. Because retarded development of morphology of decapod larvae has been shown to occur especially under conditions of stress, the incidence of such characters in A. angustipes and some related species might indicate some unfavorable factors in the respective cultures or, in our material, maybe stress exerted during the long transport of egg-bearing females from Brazil to Europe. This question remains unresolved until not only more inter-, but also more intraspecific morphological comparisons between hatches, populations, and treatments become available.

Comparing the larval morphology of American Sesarmidae, we found clear differences between Sesarma, Aratus, and Armases. Not included in this comparison was Metopaulias because it presents an abbreviated development with strongly modified larval morphology (see recent comparison in Anger et al., 1995, and Schubart and Cuesta, 1998). In the first zoeal stage of Armases and Ara$t u s$, the ratio FL/BT (FL: furcal length, BT: base of telson length) is $<1.9$, but $>2.0$ in Sesarma species. First zoeas of Sesarma have longer furcal branches than in Armases and Aratus. In the megalopa stage of Armases and Aratus, a uropod setation of 1,7 was found, whereas Sesarma has 1,6. The similarity in these characters support the presumably close relationship between the genera Armases and Aratus. At present, the larval development remains unknown for 15 American Armases and Sesarma species; it is thus possible that this apparently typical suite of characters must later be re-evaluated when more descriptions become available.

\section{ACKNOWLEDGEMENTS}

The second author thanks Prof. Dr. G. S. Moreira and the staff of the Centro de Biologia Marinha at São Sebastião (CEBIMar) for an invitation, kind hospitality, and support as a visiting scientist, as well as the German Academic Exchange Service, DAAD (Bonn), and the Coordenadoria de Aperfeiçoamento de Pessoal do Ensino Superior, CAPES (Brasilia), for financial support. Dr. D. Ismael helped to search for and eventually discovered the ovigerous A. angustipes that rendered this study possible. Kim Riesebeck provided technical assistance in the rearing experiments on Helgoland. We are grateful to Paul Clark and two anonymous referees for their comments and criticism that clearly improved the manuscript.

\section{LiTERATURE CITED}

Abele, L. G. 1992. A review of the grapsid crab genus Sesarma (Crustacea: Decapoda: Grapsidae) in America, with the description of a new genus.-Smithsonian Contributions to Zoology 527: 1-60.

Anger, K., J. Harms, M. Montú, and C. de Bakker. 1990. Effects of salinity on the larval development of a semiterrestrial tropical crab, Sesarma angustipes (Decapoda: Grapsidae).-Marine Ecology Progress Series 62: 89-94.

, D. Schreiber, and M. Montú. 1995. Abbreviated larval development of Sesarma curacaoense (Rathbun, 1897) (Decapoda: Grapsidae) reared in the laboratory.-Nauplius 3: 127-154.

Clark, P. F., D. K. Calazans, and G. W. Pohle. 1998. Accuracy and standardization of brachyuran larval descriptions.-Invertebrate Reproduction and Development 33: 127-144

Costlow, J. D., Jr., and C. G. Bookhout. 1960. The complete larval development of Sesarma cinereum (Bosc) reared in the laboratory.-Biological Bulletin 118: 203-214.

- and - 1962. The larval development of Sesarma reticulatum Say reared in the laboratory.Crustaceana 4: 281-294.

Cuesta, J. A. 1999. Morfología larval de la familia Grapsidae (Crustacea, Decapoda, Brachyura).-Ph.D. thesis. University of Seville. $291 \mathrm{pp}$. 
M. Schuh, R. Diesel, and C. D. Schubart. 1999. Abbreviated development of Armases miersii (Grapsidae: Sesarminae), a crab that breeds in supralittoral rock pools.- - Journal of Crustacean Biology 19: 26-41.

Dana, J. D. 1852. Crustacea, Part 1. In: United States Exploring Expedition during the years 1838, 1839, $1840,1841,1842$ under the command of Charles Wilkes, U.S.N. Philadelphia, v. 13. 685 pp.

Díaz, H., and J. J. Ewald. 1968. A comparison of the larval development of Metasesarma rubripes (Rathbun) and Sesarma ricordi H. Milne Edwards (Brachyura, Grapsidae) reared under similar laboratory conditions.-Crustaceana Supplement 2: 225-248.

Fransozo, A., J. A. Cuesta, and M. L. Negreiros-Fransozo. 1998. First zoeal stage of two species of Grapsidae (Decapoda, Grapsidae) and a key to such larvae from the Brazilian coast.-Crustaceana 71: 331-343.

Kowalczuk, V. G. L. 1994. Estrutura populacional de Armases angustipes (Dana, 1852) (Decapoda: Brachyura: Grapsidae) da Ilha do Farol, Caiobá, PR e seu desenvolvimento pos-embrionário sob condições de laboratório.-M.Sc. Dissertation, Universidade Federal do Parana, Curitiba, PR, Brazil.
Niem, V. H. 1996. Phylogenetic relationships among American species of Sesarma (subgenus Armases) (Brachyura, Grapsidae).-Crustaceana 69: 248-330.

Schubart, C. D., and J. A. Cuesta. 1998. The first zoeal stages of four Sesarma species from Panama, with identification keys and remarks on the American Sesarminae (Crustacea: Brachyura: Grapsidae).—Journal of Plankton Research 20: 61-84.

, R. Diesel, and D. L. Felder. 2000. Molecular phylogeny, taxonomy, and evolution of non-marine lineages within the American grapsoid crabs (Crustacea: Brachyura).-Molecular Phylogenetics and Evolution 15: 179-190.

Warner, G. F. 1968. The larval development of the mangrove tree crab Aratus pisonii (H. Milne-Edwards) reared in the laboratory (Brachyura, Grapsidae).Crustaceana Supplement 2: 249-258.

RECEIVED: 29 February 2000.

ACCEPTED: 29 January 2001. 